I urge all ACRL members to support this step, recognizing it for what it is: an investment in the future of academic libraries and librarianship.

In his eloquent report last year my predecessor reported on a number of serious issues which we continue to confront. Progress has been made on a number of them. The most significant expenditure of effort during the year has been the attempt to affect the development of a new "Operating Agreement for ALA and its Divisions." This Agreement will affect both the governance and the financing of the ACRL, the other divisions, and the ALA central structure. The ACRL objective in various forums has been to maximize the ability of ACRL to meet the needs of its members without undermining the essential services of the ALA central structure. There are embedded in the negotiations issues which may never be fully resolved. Certainly the relationships are dynamic ones. However, we do expect that some of the basic issues will be settled in the Agreement scheduled to be adopted at the Midwinter Conference in 1982.

Ninety-two years have passed since Mr. Fletcher made his motion for the formation of an association of academic librarians. Since that time, the collective efforts of academic librarians to advance our profession and the association that sustains it have borne results that, I believe, effectively disprove Baudelaire's contention that there can be no progress except in the individual.

Millicent D. Abell President, ACRL

\title{
Bibliographic Instruction
}

\section{Bibliographic Competencies for Education Students}

Students in education need an increasingly sophisticated knowledge of library resources in order to access information in the discipline. "Bibliographic Competencies for Education Students," an ACRL committee project, identifies minimal skills in the use of education materials which should be demonstrated by students at the undergraduate and graduate levels. It is intended for use by students, teaching faculty, and librarians.

Members of the Bibliographic Instruction for Educators Committee of ACRL's Education and Behavioral Sciences Section who developed the instrument are: George Jaramillo, Jim Olivetti, Virginia Parr, Hannelore Rader, Ilene Rockman, Harvey Soule, Charles Thurston, Thomas Tollman, and Joan Worley (chair).

1. To develop a logical approach to researching a topic.

a. Locate definitions of general and specialized educational terms. Information sources: Dictionary of Education; International Dictionary of Education; Terms in Reading. Rationale: To recognize dictionary sources specific to education.

b. Locate summary discussions of educational topics. Information sources: Encyclopedia of Education; Handbook on Contemporary Education. Rationale: To gain overview of topics of inquiry and learn secondary sources of research.

c. Locate resources using the library's author, subject, and title catalog(s). Information sources:
Card, Online, Fiche or Film Catalog. Rationale: To gain access to a library's holdings.

d. Locate journal articles in indexes and abstracts. Information sources: Education Index; Current Index to Journals in Education (CIJE); Child Development Abstracts and Bibliography; Educational Administration Abstracts. Rationale: To access periodical literature in education.

2. To identify major reference tools in education. Information sources: Encyclopedia of Educational Research; Second Handbook of Research in Teaching; Resources in Education. Rationale: To perform basic bibliographic research in support of teaching.

3. To identify and describe standardized tests. Information sources: Mental Measurements Yearbook; Directory of Unpublished Experimental Mental Measures. Rationale: To become acquainted with the characteristics of tests in use.

4. To locate and describe print and non-print curriculum materials, instructional aid resources. Information sources: Curriculum Review; Media Review Digest; NICEM Directories; Educators Guides to Free Films, etc. Rationale: To locate critical reviews of classroom materials, to effectively access audiovisual and graphic aids in instruction.

5. To locate book reviews in education and related fields. Information sources: Book Review Digest; Current Book Review Citations. Rationale: To access critical commentary on books and authors in education. 
NOTE: The following competencies may be more relevant to graduate level research.

6. To utilize state and federal government publications. Information sources: Monthly Catalog of United States Government Publications; Congressional Information Service; United States Code; state codes. Rationale: To retrieve information issued by government agencies and legislatures.

7. To locate statistics relevant to the school community in government publications and other sources. Information sources: Digest of Educational Statistics; American Statistics Index; Statistical Reference Index. Rationale: To effectively utilize demographic, financial, and other types of data for school planning.

8. To make a general assessment of an author's competence. Information sources: Directory of American Scholars; Contemporary Authors; Social Sciences Citation Index. Rationale: To gain knowledge of the author's credibility and position in the field.

9. To distinguish characteristics of general, scholarly, and professional association journals. Information sources: Education and EducationRelated Serials, A Directory; Education/Psychology Journals, A Scholar's Guide. Rationale: To gain awareness of the variety of periodicals covering education and to understand the scope and purpose of each.

10. To understand purpose and scope of professional associations and their major publications. Information sources: Directory of Education
Associations; Association for Supervision and Curriculum Development Yearbook. Rationale: To acquaint student with significant research in subject-specific area.

11. To select and use computerized information services. Information sources: ERIC; Psychological Abstracts (Psyc Info). Rationale: To understand the function of computerized data bases and to appreciate the diffusion of information.

12. To identify theses and dissertations. Information sources: Dissertation Abstracts International; Comprehensive Dissertation Index; Masters Theses in Education. Rationale: To gain awareness of educational research at the graduate level.

13. To identify and locate information resources available outside the local community, using general and national bibliographies. Information sources: A Cuide to Sources of Educational Information; National Union Catalog; British Museum Catalog. Rationale: To become familiar with significant resources beyond the local library,-Submitted by Joan H. Worley, chair, EBSS Bibliographic Instruction for Educators Committee.

Editors Note: This document is available in tabu lar form, free to members, $\$ 1$ to non-members, from ACRL/ALA, 50 E. Huron St., Chicago, IL 60611. All orders should include a self-addressed mailing label and $30 \propto$ in postage.

\title{
Midwest Library Service Announces Its Newly Expanded CONTINUATION AND STANDING ORDER SERVICE
}

We invite you to submit your Continuations List to us for prompt, efficient processing. Our publisher base includes approximately 500 selected publishers. We are thoroughly knowledgeable in all aspects of Standing Order procedures. For a copy of our new brochure on "CONTINUATION \& STANDING ORDER SERVCE' please call us, using our TOLL-FREE WATS Line: 1-800-325-8833, or else write:

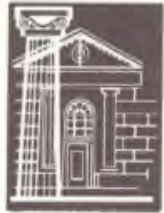

\author{
Mr. Howard Lesser \\ President \\ Midwest Library Service \\ 11443 St. Charles Rock Road \\ Bridgeton, Mo. 63044
}

Once your order is received, a Personal Customer Service Representative will be assigned to your library to assist you. 


\section{Only a rare bestseller becomes a classic. \\ a}

Few

\section{bestsellers}

withstand the test of

time. Titles and story lines

are scon forgotten, lost in the piles of the oncepopulat.

Occasionally a classic emerges - a work so strong and fine that its reputation grows to a status beyond popularity.

Bookjobbers are often like bestsellers - gradually tading in importance and quality. Yankee Book Peddler is a bookjobber that intends to stay on the bestseller list for a long, long time.

Over the years we've held to a rare story line based on excellence, attention to detail and service. We have established a reputation as one of the finest library bookjobbers 


\section{LIBRARY MANAGEMENT DEGREE}

The Graduate Library School of the University of Chicago has received a grant of $\$ 250,000$ from the Council on Library Resources to support a special program designed to lead to the award of a Certificate of Advanced Study in Library Management. The grant is for two years and may be renewed for a third.

Among the objectives of the program, which is geared towards academic and research libraries, are: 1) to provide students with an opportunity to study formally general management issues, problems, and techniques; 2) to broaden and deepen students' knowledge of the problems facing large academic, research and other libraries; 3) to develop the ability of students to conceptualize, analyze, and obtain evidence for recommending solutions to management problems; 4) to help prepare students for successful occupancy of middle and ultimately upper level management positions in libraries; and 5) to increase the effective. ness of large academic, research and other libraries by strengthening their management structure, processes and personnel.

The course of study proposed will have four components: a group of courses taken in the Graduate Library School; a group of courses taken in the Graduate School of Business; an Investigative Internship to be held in one of the participating academic and research libraries; and a Management Seminar which will be conducted throughout the course of the program.

Students in the program will be known as CLK Library Management Fellows. They will already have a first professional degree, and five or more years of successful library experience. Libraries participating in the program by providing possible sites for the Investigative Internship are: the Newberry Library, Northwestern University, the John Crerar Library, the University of Illinois at Chicago Circle, the University of Chicago, and

\section{Subscription Price Increase}

Effective September 1, 1981, the price for a one-year subscription to C $\& R L$ News will be \$10. The ACRL Board of Directors has approved the increase to help offset the effects of inflation and maintain the current quality of the magazine. The increase will affect subscribers only and not members, who receive $C \triangleleft R L$ News as part of their membership benefits.

The price of a subscription to College \& $R e$ scarch Libraries will also rise from $\$ 25$ to $\$ 35$ beginning with the September 1981 issue.

\section{Articles Wanted}

C $\& R L$ News asks readers to submit articles to be considered for publication in the monthly columns for continuing education and bibliographic instruction. Articles should be no longer than 1,000 words in length. Topics within the fields of continuing education and bibliographic instruction might include: innovative programs at the author's institution; organization and enhancement of a program; or educating others to develop/teach/monitor these programs. Materials submitted should be of practical or topical interest, rather than scholarly articles. Anyone interested should contact C. Brigid Welch or George $M$. Eberhart at ACRL/ALA, 50 E. Huron St., Chicago, IL 60611; (312) 944-6780.

the Chicago Public Library.

The first intake of students will be in the spring term of 1982. For further information contact: W. Boyd Rayward, Dean, Graduate Library School, 1100 E. 57th St., Chicago, IL 60637.

\section{CINCINNATI SURVEYS AUTOMATION OPTIONS}

The University of Cincinnati libraries are performing a planning study which will present a set of options concerning automated record systems to its vice presidents in September, 1981. Work is now underway on a user survey of faculty, students, staff, and administrators. The goal is to find out how current manual record systems help or hinder research and instructional activities.

Simultaneously, the libraries are observing national trends in library automation. Charles B. Osburn, vice provost for university libraries, said: "We have nearly ten years of OCLC data; our job now is to find the most cost-effective options for the $80 \mathrm{~s}$. Having waited until this point to consider systems, there is now much to choose from."

Cincinnati will proceed conservatively, implementing and operating one function at a time in order to maintain financial and administrative control. The university's five independent library jurisdictions (including medical, law, and two offcampus centers) have indicated that circulation and the serial record are the highest ranked candidates for automation.

Ellen Miller, director of library systems development, is in charge of the planning study. She asks libraries to send word of operative systems (whether vendor or library created) available for acquisition by the University of Cincinnati libraries. Send information to: Ellen Miller, Room 466, Central Library, University of Cincinnati, Cincinnati, OH 45221. 


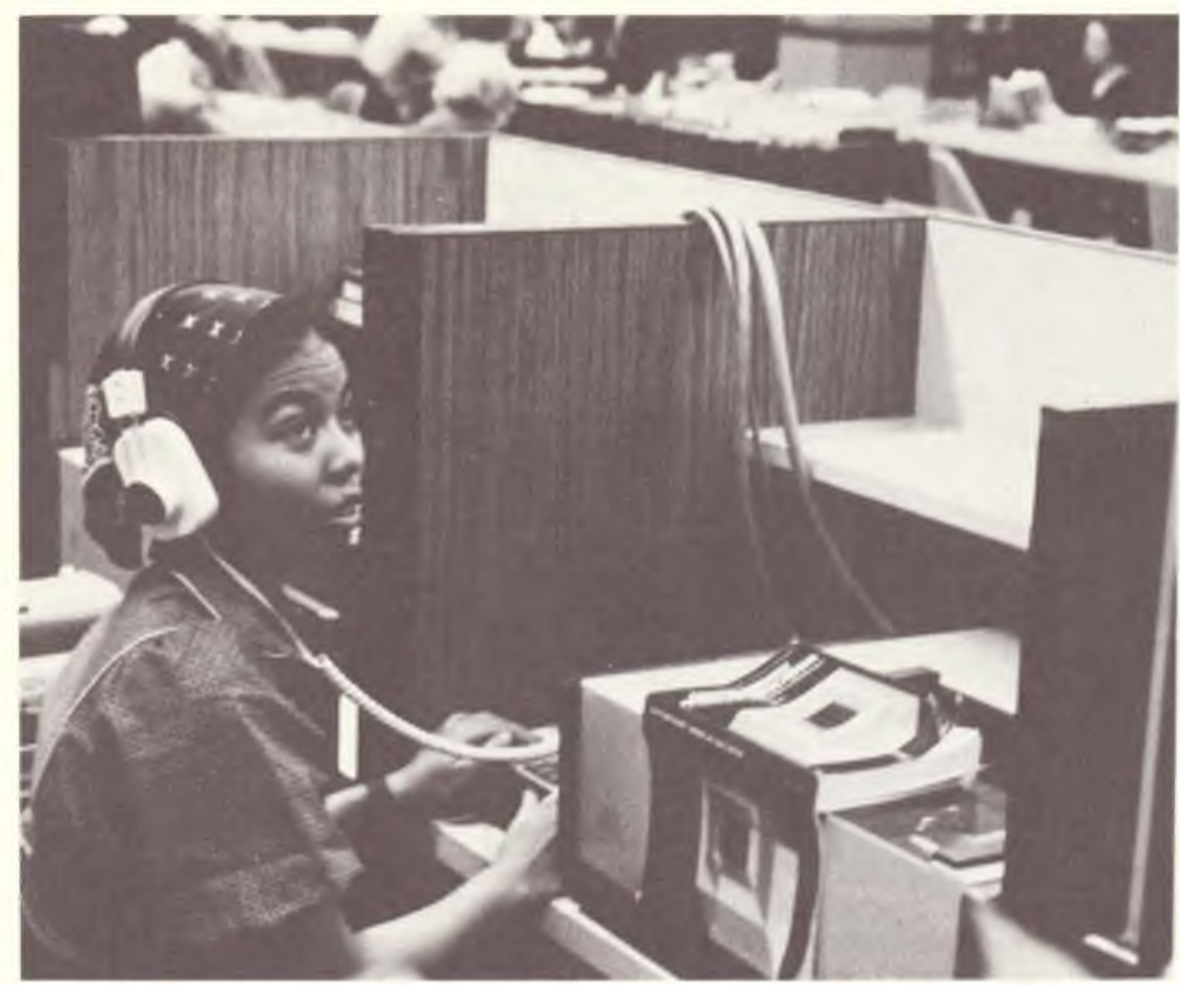

\section{This is a blind student. Reading.}

Blind people are entering colleges and universities in record numbers, challenging traditional ideas about the careers they can enjoy. And they're achieving impressive records, going on to work as programmers, lawyers, engineers, teachers. But handling the reading required is a perpetual problem, even with readers and recordings available.

Now an important new tool exists for blind students and researchers: the Kurzweil Reading Machine. This amazing computer reads books, journals and other printed material aloud...it works as a "talking calculator"...and it speaks the words displayed on a computer terminal's video screen.

In 35 universities and 200 other settings nationwide, the Reading Machine is helping blind people help themselves. If you'd like to become part of this exciting trend. Kurzweil's funding and program development specialists are available to consult with you. Contact us for more information or a demonstration -- and be sure to visit the Kurzweil booth at the ACRL Conference to hear the revolutionary Reading Machine at work.

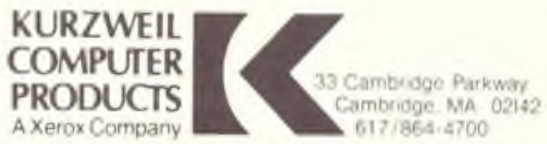

